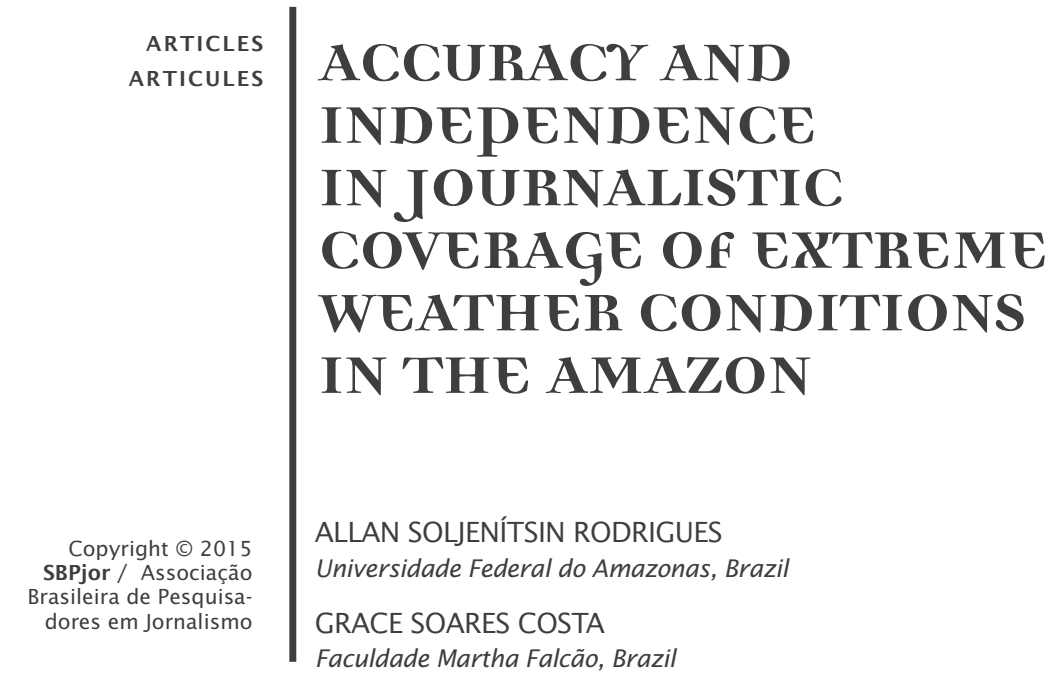

\begin{abstract}
The article presents some of the results obtained in the research project "Journalism and environment in the Amazon: the coverage of extreme weather events by the press of Manaus", conducted by Journalism Laboratory of Advanced Studies in and on the Amazon (LABJAM), which had as its object the news coverage of occurring droughts in the Amazon in 2005 and 2010 carried out by the two major newspapers in Manaus. The research pointed to the little contribution of news coverage for informed decisionmaking by the residents of the main capital of the Amazon on issues related to global climate change and its effects.

Keywords: Journalism; Amazon; drought; Events Climate Extremes.
\end{abstract}

\title{
PRECISÃO E INDEPENDÊNCIA NAS COBERTURAS JORNALÍSTICAS DE EVENTOS CLIMÁTICOS EXTREMOS NA AMAZÔNIA
}

RESUMO - O artigo apresenta alguns dos resultados obtidos no projeto de pesquisa "Jornalismo e meio ambiente na Amazônia: a cobertura de eventos climáticos extremos pela imprensa escrita de Manaus", realizado pelo Laboratório de Estudos Avançados de Jornalismo na e sobre a Amazônia (LABJAM), que teve como objeto a cobertura jornalística das secas ocorridas na Amazônia nos anos de 2005 e 2010 realizada pelos dois jornais de maior circulação de Manaus. A investigação apontou a pouca contribuição da cobertura jornalística para tomadas de decisão esclarecidas por parte dos moradores da principal capital da Amazônia sobre as questões relacionadas às mudanças climáticas globais e seus efeitos.

Palavras-chave: Jornalismo; Amazônia; Seca; Eventos Climáticos Extremos.

\section{EXACTITUD E INDEPENDENCIA EN LAS COBERTURAS PERIODÍSTICAS EVENTOS CLIMÁTICOS EXTREMOS EN LA AMAZONÍA}

RESUMEN - El artículo presenta algunos de los resultados obtenidos en el proyecto de investigación "El periodismo y el medio ambiente en la Amazonia: la cobertura de los eventos climáticos extremos por la prensa de Manaos", Ilevada a cabo por el Laboratorio de Periodismo de Estudios Avanzados en y sobre la Amazonia (LABJAM), que tenía por 
objeto la cobertura de noticias de ocurrir sequías en el Amazonas en 2005 y 2010 llevó a cabo por los dos principales periódicos en Manaus. La investigación señaló la poca contribución de la cobertura informativa para la toma de decisiones informadas por los residentes de la capital principal del Amazonas en temas relacionados con el cambio climático global y sus efectos.

Palabras clave: Periodismo; Amazonas; Sequía; Eventos climáticos extremos.

\section{INTRODUCTION}

This article is an interdisciplinary study on the media coverage of the 2005 and 2010 Amazon droughts. The purpose of the study was to determine if the press in the region managed to educate their audience efficiently on droughts and their impact. We used methodological tools and theoretical frameworks in the areas of Communication, Journalism, Sociology and Political Science to report our findings. Our goal was to determine whether two of the major newspapers in the region (the Diário do Amazonas and A Crítica) had provided quality scientific and environmental information when covering extreme weather conditions.

This study investigated the quality of journalism for extreme weather conditions in the Amazon. Democratic states uphold the rights of the press to inform and of citizens to receive information, making them essential components of a democracy (MELO, 2009). This makes journalism socially responsible for providing people with the information they need in order to govern themselves (KOVACH; ROSENSTIEL, 2003) as well as providing its citizens with the necessary tools to exercise their rights and give them a voice with which they can express their concerns. Given these premises, we believe that good quality journalism can help qualify and expand debates on environmental issues and their impact on the Amazon and its population.

Investigating the quality of journalism on extreme weather conditions in the Amazon meant looking at the core principles of journalism. Traquina (2005) states that journalism has added new principles and values to its craft over time which currently guide the profession, ensuring the quality of the information it transmits to society. 
According to Hymes (1980), these shared interpretations of reality united journalists together as a group, as an interpretive community. Since listing all the principles of journalism and the ethical discussions that come with them is quite a daunting task, we decided to adopt the proposition from Kovach \& Rosenstiel (2003) who compiled interviews from 300 journalists into a list of nine principles for journalism to achieve its goal. We also took into account the roles of scientific and environmental journalism as defined by Oliveira (1990) and Bueno (1984), respectively.

This study is a contribution towards outlining the quality of scientific and environmental information communicated by newspaper journalism on climate change in the Amazon. We are hopeful that examining this issue will provide a theoretical base for the qualification of journalism on environmental issues. Our goal is to contribute to a greater understanding of science and the environment in society; something that is essential towards helping informed decisions to be made on the environment and development of the Amazon.

\section{PRINCIPLES OF JOURNALISM}

A quantitative and qualitative study on media coverage of the 2005 and 2010 Amazon droughts using the content analysis method requires building categories of objective analysis. The purpose of this study was to build these categories based on the role journalism has in a democracy, its core principles and its specific elements of scientific and environmental reporting. Listing the principles of journalism and the ethical discussions surrounding them is no easy task; they are constantly being updated and there is no official consensus. Below is a list of the principles of journalism as defined by Kovach and Rosenstiel (2003) with further theoretical contributions from Brazilian researchers in the field of communication:

- Commitment to the truth: the first commitment of journalism must be to the truth (PENA, 2005). We must make it clear that we are referring to Kovack and Rosenstiel's concept (2003) of journalistic truth being different from philosophical truth; it is built gradually, fact by fact, in order to understand all the facts.

- $\quad$ Loyalty to public interest: this principle leads us to the question of "journalistic independence": the fact that 
journalism is financed by the private sector but serves the public interest (KOVACH; ROSENSTIEL, 2003).

- $\quad$ Verifying: serving the public interest means getting closer to the truth. In order to do that, it is necessary to verify the published information. Kovach and Rosenstiel (2003) believe that this principle separates journalism from other areas such as entertainment, advertising, literature, or art.

- Independent sources: according to Chaparro (2001), the organization and discursive power of sources is the most important change to have happened to journalism over the last forty years. The concern over the influence sources have on journalism also applies to the field of judgment. Kovach and Rosenstiel (2003) warn us that stricter rules will not necessarily guarantee that a journalist will be free of personal or intellectual commitments.

- $\quad$ Being an independent regulator of power: this principle of protecting public interest applies to the government just as much as it does to other powerful institutions in society (KOVACH; ROSENSTIEL, 2003). It is up to journalists to break free from this bipolar concept of conflicting powers (journalism versus government) and look at the third side of this story in need of representation: the people.

- $\quad$ Providing a forum for public comments and criticism: according to Kovach and Rosenstiel (2003) it is best to avoid addressing the extreme sides to issues since they tend to exclude the majority of citizens and are hardly conciliatory. When this principle is not followed, discussions become rife with stories of spectacles and fiction.

- $\quad$ Presenting the issue in an interesting and relevant way: this principle refers to two aspects of journalism: choosing news (what is relevant) and text production (reporting interesting stories). Pena (2005) considers that revealing how news is produced is not just a key to understanding its meaning; it also contributes towards a more democratically-improved society. 
- Journalists must be conscientious: this principle advocates that all journalists - from newsrooms to the Board of Directors - must have a personal sense of ethics and responsibility; a moral guidance (KOVACH; ROSENSTIEL, 2003).

\section{SCIENTIFIC AND ENVIRONMENTAL JOURNALISM}

\subsection{SCIENTIFIC JOURNALISM:}

If journalism is still looking for academic recognition as an object and a field of research, then the same is true for scientific information. That's why we need to establish further contexts and concepts about scientific journalism. When speaking about the role of scientific journalism, Ivanissevich (2005) believes that scientific journalism must stimulate debates on controversial issues such as embryo cloning, genetically modified food, and global climate change. This is not only because of the ethical responsibility the media have to do so, but also because it is appealing to the public; it attracts readers and sells the product (news). Bueno (1984) considers scientific journalism to be composed of six basic functions:

- Informative: implicit in the very concept of scientific journalism. It is the promulgation of scientific facts and technological information to give all citizens the chance to learn about new scientific discoveries and their political, economic and socio-cultural implications;

- Educational: scientific journalism should be cognizant of the fact that, in many cases, it is the only source of public information on science and technology;

- Social: concerned with scientific and technological information reaching a broader context. It provides for the discussion of issues and technology in the light of societal aspirations, and it matches the public's interests to the objectives of scientific production and dissemination;

- $\quad$ Cultural: scientific journalism should work towards preserving and developing culture, and resist any attempts of aggression directed at cultural values; 
- $\quad$ Economic: it is up to science journalism to contribute towards improving communication between institutes, universities and national research centers and the productive sector;

- $\quad$ Political and ideological: scientific journalism is often funded by large multinational companies which use it to inform the population about their scientific and technological achievements. Taking that into account, scientific journalism should avoid being a mere puppet for these companies and only legitimize them in society.

\subsection{ENVIRONMENTAL JOURNALISM}

The social function of environmental journalism is to be politically, socially and culturally committed to sustainable development and an improved quality of life. "This is the only way it will be able to find the strength to withstand the assaults and pressure that come from governments, companies, even universities and research institutes, many of which are sponsored by or hostages of larger interests" (BUENO, 2007, p.29). Achieving this goal means looking at some of the principles and procedures that the environmental journalism community has adopted over the years. Analysis of the coverage on the 2005 and 2010 Amazon droughts (the object of this study) was supported by reviewing the available literature on the issue. Here are eight convergent points mentioned by the authors:

a) Source diversity:

Environmental reports must make room not only for those who already have a voice in the media (authorities, researchers, businesspeople and politicians) but also those commonly silenced by the media (professional associations, community leaders, community members affected by environmental problems, etc.).

b) Independent sources:

Journalists should not choose the subjects for day-to-day coverage on the environment that communication agencies, press offices, researchers, NCOs and others suggest to without understanding what the reasons and interests behind them are first (BUENO, 2007). 
c) Making room for debate:

This point is related to the previous one in that when a diverse range of sources are chosen, it is only natural that contrasting opinions will exist. When they favor sources from the field of academics, the political world (authorities) and the business community, environmental journalists end up adopting an elitist, authoritative and non-democratic attitude as they are denying ordinary citizens any room for speech and experiences (BUENO, 2007).

d) Avoiding tabloid journalism:

This item is about understanding (something that is rare in newsrooms) that environmental journalism is not tabloid journalism. "The rhetorical enthusiasm often tends to be blind to the obvious - arguments and facts are two different things." (FONSECA, 2004, p.137). The author explains that this type of sensationalist behavior occurs because the press does not always have public debate on its mind. On the contrary, it prefers to report on environmental disasters using headlines that are shocking or border on terror, almost forging a relationship between ecology and fear.

e) Not everything comes down to economic issues:

Some professionals in the press are eager to recognize the importance of environmental aspects in terms of their economic impact, and they tend to sum them up accordingly. It is still rare to find national press coverage that is creative, meaning that it studies, looks at, and explores the many connections between the environment and the world of money, foreign trade and finance (SCHARF, 2004).

f) Combining journalism and education:

Environmental journalism should allow for citizen participation in talks on sustainable development. It plays an educational role in standardizing concepts, and disseminating information, knowledge and experiences. Because of the ecological crisis and climate change, the press must also be responsible for educating and transforming, not just informing (BELMONTE, 2004).

g) Avoiding fragmented coverage:

This fragmentation, often a result of the way journalism is produced, weakens the coverage of environmental issues (BUENO, 2007). It makes journalists a little indifferent towards environmental issues in the sense that they disregard the context of events, meaning 
people are not informed about what had happened before and the likely consequences of it (SCHARF, 2004).

h) Revolutionary feature and engagement:

Environmental journalists see themselves as participants in a process that is revolutionary and encourage the engagement of their peers, perhaps because they are close to causes that look to change the current development model and, consequently, the need for thorough changes in societies. Authors like Bueno (2007) and Geraque (2004) observe that fulfilling this revolutionary role means not being a distributor (partial) or "green" (environmental activist).

\section{RESEARCH METHOD}

As we stated earlier, the research is based on a qualitative and quantitative methodology. We used content analysis because it is one of the most efficient methods of tracing information due to its superior ability to reach conclusions about what was reported (SANTOS, 1997). The qualitative method is applied to an analysis of in-depth interviews with journalists, qualified readers and sources. This made it possible to assess other aspects that would not have been possible to analyze by just investigating printed reports on the 2005 and 2010 droughts. This research used content analysis to detect trends and analysis patterns in newsworthy material, guidelines and schedules.

Supported by the premises described above, we examined the journalistic content published in A Crítica and Diário do Amazonas on the droughts of 2005 and 2010. These daily newspapers were chosen because they are the first and second, respectively, in terms of circulation in the state of Amazonas. 112 newspaper articles published from August to December were collected and analyzed on the phenomena (51 on the 2005 drought and 61 on the 2010 drought) from the newspapers A Crítica (28 articles in 2005 and 41 in 2010) and Diário do Amazonas (23 in 2005 and 20 in 2010) and were classified under categories of analysis in order to understand their content and formats. The criteria selection focused on the texts that had the keywords dry, drought or low water in them; that were published in the 2 nd half of 2005 and 2010 (low tide period for the rivers in the Amazon); and that belong to the genre of informative journalism in the form of news and articles as described by Melo (2010). 
Classification followed the principles set forth by Bardin (2010). The analysis aimed to assess the quality of the scientific and environmental information of the 2005 and 2010 drought coverage made from the newspapers A Crítica and Diário do Amazonas, the corpus of which was presented in the previous paragraph. The choice of analysis categories was based on the principles of journalism and its scientific and environmental genres and premises for the categorization of content analysis. The defined categories were:

- $\quad$ Accuracy: analyzes the credibility and accuracy of the information published on the 2005/2010 droughts and their causes and effects, without any tabloid journalism. It encompasses the general principles of journalism such as commitment to truth, loyalty to the public interest, verifying, and the journalists' obligation to their conscience. Also the quality of tabloid-free environmental journalism.

- Independence: analyzes whether the government was questioned about its responsibilities surrounding the causes and effects of the droughts in 2005/2010. It includes the general principle of journalism of being an independent power regulator.

- Plurality: analyzes the space given within the article for the various voices to be heard on the $2005 / 2010$ droughts. It covers the general principles of journalism to promote a forum for public criticism and comments, promote independent sources, and for including social, informational, political, cultural and economic functions of science journalism. This category also includes qualities of source diversity, making room for debate and the revolutionary feature and engagement of environmental journalism.

- Context: analyzes the causes and consequences of the droughts in 2005/2010 and their social, cultural, economic, environmental and political implications. It brings together the qualities inherent in environmental journalism in order to avoid fragmenting the coverage and summarizing everything in terms of the economy. 
- $\quad$ Awareness: using the articles not only for reporting on extreme weather conditions such as the 2005 and 2010 droughts, but also for raising awareness within the population of the need to make informed decisions on the environment. It takes journalism's main principle of presenting the issue in an interesting and relevant way and integrates it with the educational role of science journalism, looking to combine journalism with environmental journalism education.

After establishing the categories for analysis, we developed a questionnaire in order to ascertain whether the articles contained the principles of journalism and its scientific and environmental subgenres. The questions were formulated and distributed according to the categories in the following chart:

Chart 1: Categories of analysis and questions from the questionnaire

\begin{tabular}{|c|c|c|}
\hline $\begin{array}{l}\text { Analysis } \\
\text { Category }\end{array}$ & $\begin{array}{l}\text { Elements } \\
\text { analyzed in } \\
\text { the articles in } \\
\text { categories }\end{array}$ & $\begin{array}{l}\text { Closed questions for } \\
\text { analysis of reports }\end{array}$ \\
\hline Accuracy & $\begin{array}{l}\text { The credibility and } \\
\text { accuracy of information } \\
\text { published on the } \\
2005 / 2010 \text { droughts } \\
\text { and their causes and } \\
\text { effects, without any } \\
\text { tabloid journalism. }\end{array}$ & $\begin{array}{l}\text { - What is the main focus of the } \\
\text { article? } \\
\text { What was the highlighted cause } \\
\text { for the } 2005 / 2010 \text { droughts? } \\
\text { Do the articles on the causes and } \\
\text { consequences use future modals } \\
\text { such as would, should, could } \\
\text { etc., expressions like probably } \\
\text { and supposedly, or verbs in the } \\
\text { gerund (investigating, calculating, } \\
\text { etc.)? }\end{array}$ \\
\hline Independence & $\begin{array}{l}\text { Questioning the } \\
\text { government's } \\
\text { responsibility regarding } \\
\text { the causes and effects } \\
\text { of the droughts in } \\
2005 / 2010 \text {. }\end{array}$ & $\begin{array}{l}\text { - Was the government questioned } \\
\text { about its actions in the aftermath } \\
\text { of the } 2005 / 2010 \text { droughts? } \\
\text { Does the article address the } \\
\text { effective implementation } \\
\text { and measures taken by the } \\
\text { government to repair the effects } \\
\text { of the droughts? } \\
\text { Did it show the readers what the } \\
\text { government's responsibilities are? } \\
\text { Did the article address the } \\
\text { presence or lack of government } \\
\text { policies towards preventing } \\
\text { or repairing the effects of the } \\
\text { droughts? }\end{array}$ \\
\hline
\end{tabular}




\begin{tabular}{|c|c|c|}
\hline Plurality & $\begin{array}{l}\text { The space given within } \\
\text { the article for various } \\
\text { voices to be heard } \\
\text { on the } 2005 / 2010 \\
\text { droughts. }\end{array}$ & $\begin{array}{l}\text { - What is the nature of the sources } \\
\text { used in the article? } \\
\text { - What voices were given space in } \\
\text { the article? } \\
\text { - How many climate and } \\
\text { environmental researchers where } \\
\text { interviewed for the article? } \\
\text { - How many scientific opinions } \\
\text { are presented in the articles } \\
\text { addressing the environmental } \\
\text { causes and consequences? }\end{array}$ \\
\hline Context & $\begin{array}{l}\text { The causes and } \\
\text { consequences of the } \\
\text { droughts in } 2005 / 2010 \\
\text { and their social, } \\
\text { cultural, economic, } \\
\text { environmental and } \\
\text { political implications. }\end{array}$ & $\begin{array}{l}\text { Did the article report on the roots } \\
\text { of the problem of the droughts? } \\
\text { Did the article present expert } \\
\text { opinions on the diagnosis and } \\
\text { possible prognosis? } \\
\text { - Did the article correlate the } \\
\text { problem of the drought with the } \\
\text { global environmental issue? } \\
\text { Did the article correlate the } \\
\text { problems of the drought with } \\
\text { economic, political or cultural } \\
\text { issues? }\end{array}$ \\
\hline Awareness & $\begin{array}{l}\text { Using the articles not } \\
\text { only for reporting } \\
\text { on extreme weather } \\
\text { conditions such } \\
\text { the } 2005 \text { and } 2010 \\
\text { droughts, but also } \\
\text { raising awareness within } \\
\text { the population of the } \\
\text { need to make informed } \\
\text { decisions on the issue of } \\
\text { the environment. }\end{array}$ & $\begin{array}{l}\text { - In addition to reporting on the } \\
\text { effects of the drought, did the } \\
\text { article also present information to } \\
\text { the reader towards understanding } \\
\text { the drought and global } \\
\text { environmental issues? } \\
\text { - In addition to reporting on the } \\
\text { effects of the drought, did the } \\
\text { article also translate the specific } \\
\text { terms and expressions used for } \\
\text { environmental issues which are } \\
\text { unfamiliar to readers? } \\
\text { - In addition to reporting on the } \\
\text { effects of the drought, did the } \\
\text { article also educate the readers } \\
\text { on the environment? } \\
\text { In addition to reporting on the } \\
\text { effects of the drought, did the } \\
\text { article also show the readers how } \\
\text { environmental issues affect them } \\
\text { and what they can do about it? }\end{array}$ \\
\hline
\end{tabular}

Source: guide made by the researcher / 2013

Analyzing the articles on the droughts of 2005 and 2010 helped paint a picture of the coverage and compare the principles of journalism and its scientific and environmental subgenres, as well as identify the social actors involved in the production of news (reporters and sources). However, a study which focuses only on messages (issues) does not provide sufficient information towards understanding the organizational logic behind the production of 
messages (SHOEMAKER and REESE, 1996) or feedback from the sources and readers. According to Laswell (1936), content analysis accurately describes exactly what is said about a particular topic in a particular place at a particular space.

We believe that this research provides advances because it is not limited to studying just the message (restricted to the sender) as most studies on journalism that we compared our work with had done. In order to reach the objectives, we looked more broadly at the communication process between newspapers and their readers. We used the qualitative method for this, doing in-depth interviews with journalists who are involved in the production, review, and approval of texts; with the sources that provided them information, and with qualified readers (scientists, civil society and public decision makers). Weber (1990) asserts that using both qualitative and quantitative aspects produces the best studies of content analysis in texts.

After categorizing the quantitative data taken from the content analysis, the scripts were written for the in-depth interviews. The purpose of the interviews was to get the opinion of respondents (scientists, civil society and public decision makers) on the content analysis results and to investigate issues that were not possible to investigate through reading the texts alone. This method allows us to go beyond the traditional formulation of inferences based on quantitative results because the social actors involved in producing the articles and the sources that give meaning to them could see the numbers in front of them and explain the context behind them. The methodology also provided information which came directly from the people involved in publications and from qualified readers (researchers, nongovernmental organizations, and politicians involved in making public policies about the environment) about topics such as censorship in the newsrooms, the preparation, or lack of it, when covering environmental issues and how these readers analyzed the coverage. Looking at the results obtained through qualitative and quantitative measures, the researchers were able to use the principles of journalism to reach conclusions about the quality of coverage, its scientific and environmental genres, and the collected data. In this article, we present only the results for the accuracy and independence categories. 


\section{ACCURATE COVERAGE:}

Analyzing accuracy through content analysis and interviews allowed us to ascertain the credibility and accuracy of the information published on the causes and consequences of the droughts in 2005 and 2010, and any tabloid journalism was used. We will cross match the data from the content analysis with the interviews in order to indicate possible deviations, and also to understand the process behind news production and look for ways towards improving the quality of the scientific and environmental information provided in coverage of extreme weather conditions in the Amazon. The analysis will look at the data from both newspapers' coverage, since the results from the analysis of texts and interviews do not show any differences between the two periods in any of the established categories.

The results from the content analysis of the reports on the 2005 and 2010 droughts for the accuracy category (see Table 1) showed that coverage focused mainly on the consequences of the droughts, the ordeals the people lived through, and the actions the government took towards alleviating the social impacts of the phenomena. Out of all the articles published by the two newspapers, $63.4 \%$ of them reported on how the diminishing tide isolated communities, affected the supply of drinking water, shut down ports, hindered school transport, prevented people from making their way to the polling stations in the 2010 election, restricted the staff work from the Brazilian Institute of Geography and Statistics (IBGE) in 2005, made navigating the rivers of the Amazon difficult and, consequently, affected the transport of cargo and passengers around the Amazonas and in some neighboring states. The loss of fish in lakes with low oxygen levels, the arrival of food and fuel to municipal centers, and various government actions to alleviate the suffering of those affected were also featured in the pages of A Crítica and Diário do Amazonas. 
Table 1: Results of Content Analysis in the Accuracy Category

\begin{tabular}{|c|c|c|c|c|c|}
\hline \multirow{2}{*}{$\begin{array}{l}\text { What is the main } \\
\text { focus of the article? }\end{array}$} & \multicolumn{2}{|c|}{ A Crítica } & \multicolumn{2}{|c|}{$\begin{array}{c}\text { Diário do } \\
\text { Amazonas }\end{array}$} & \multirow{2}{*}{$\begin{array}{c}\text { General } \\
2005 / 2010\end{array}$} \\
\hline & $\begin{array}{c}2005 \\
\%\end{array}$ & $\begin{array}{c}2010 \\
\%\end{array}$ & $\begin{array}{c}2005 \\
\%\end{array}$ & $\begin{array}{c}2010 \\
\%\end{array}$ & \\
\hline $\begin{array}{c}\text { Consequences of the } \\
\text { droughts }\end{array}$ & 67.9 & 63.4 & 65.2 & 55.0 & 63.4 \\
\hline Causes of the droughts & 7.1 & 4.9 & 0.0 & 0.0 & 3.6 \\
\hline Others & 17.9 & 31.7 & 34.8 & 55.0 & 33.0 \\
\hline \multirow{2}{*}{$\begin{array}{c}\text { What was the cause } \\
\text { given for the } 2005 \\
\text { drought? }\end{array}$} & \multicolumn{2}{|c|}{ A Crítica } & \multicolumn{2}{|c|}{$\begin{array}{c}\text { Diário do } \\
\text { Amazonas }\end{array}$} & General \\
\hline & $\begin{array}{c}2005 \\
\%\end{array}$ & $\begin{array}{c}2010 \\
\%\end{array}$ & $\begin{array}{c}2005 \\
\%\end{array}$ & $\begin{array}{c}2010 \\
\%\end{array}$ & $2005 / 2010$ \\
\hline Climate Changes & 7.1 & 4.9 & 0.0 & 0.0 & 3.6 \\
\hline Normal water cycle & 0.0 & 0.0 & 0.0 & 0.0 & 0.0 \\
\hline $\begin{array}{l}\text { It did not give any } \\
\text { causes }\end{array}$ & 78.6 & 87.8 & 73.9 & 85.0 & 82.1 \\
\hline Others & 14.3 & 7.3 & 26.1 & 15.0 & 14.3 \\
\hline $\begin{array}{l}\text { Do the articles on } \\
\text { the causes and }\end{array}$ & \multicolumn{2}{|c|}{ A Crítica } & \multicolumn{2}{|c|}{$\begin{array}{c}\text { Diário do } \\
\text { Amazonas }\end{array}$} & General \\
\hline $\begin{array}{l}\text { future modals } \\
\text { such as would, } \\
\text { should, could } \\
\text { etc., expressions } \\
\text { like probably and } \\
\text { supposedly, or } \\
\text { verbs in the gerund } \\
\text { (investigating, } \\
\text { calculating, etc.)? }\end{array}$ & $\begin{array}{c}2005 \\
\%\end{array}$ & $\begin{array}{c}2010 \\
\%\end{array}$ & $\begin{array}{c}2005 \\
\%\end{array}$ & $\begin{array}{c}2010 \\
\%\end{array}$ & $2005 / 2010$ \\
\hline Yes & 33.3 & 0.0 & 0.0 & 0.0 & 10.0 \\
\hline No & 66.7 & 100.0 & 100.0 & 100.0 & 90.0 \\
\hline
\end{tabular}

Source: taken from the researchers

Focusing only on the consequences and hardly addressing the causes of the 2005 and 2010 droughts affects the accuracy of the coverage. Bueno (2007, p.41) has this to say about environmental agenda: "it is unreasonable to narrow the focus down too much (can't see the forest for the trees) because the environment is an immense issue". In other words, focusing coverage only on the consequences does not educate people on the reasons for the extreme weather conditions and consequently does not prepare people for future ones. This brings us to the journalistic principle of loyalty to the public 
interest because choosing to focus on consequences only shows the most dramatic aspects of the event, something done in order to maximize sales and meet the demands of newspapers as capitalist enterprises. It is possible to go beyond these immediate corporate interests and still increase revenue by offering broader materials (KOVACH and ROSENSTIEL, 2003).

Despite prevalent reports on the consequences of the drought in both newspapers, their approaches were different in both 2005 and in 2010. A Crítica went with covering the phenomena as an unnatural event and sent their reporters and photographers to some of the affected cities to give reports on the people's suffering. The photo coverage and stories told in $A$ Crítica provided readers with images of stranded boats, dry lakes, fish dying from lack of oxygen, people relating their difficulties of getting drinking water and food, and the stories of those who ended up having to travel long distances along the riverbed on foot to schools and municipal offices, something they used to do by boat or canoe before the disaster. Reporting on the actions taken by government, monitoring the rivers, the measures taken by Civil Defense, and the state and federal politicians who visited the state were the issues covered by A Crítica. On the other hand, Diário do Amazonas decided to dedicate less space to the droughts, and preferred to focus on the capital, taking a more reserved stance on the uncommon events in the region which deserve wider press coverage. Consider the following excerpt:

In the beginning we had no idea it would become something historical. We stress the importance of getting stories every day in the paper and encourage reporters to go after the facts. It was more about reacting to the events (Aruana Brianezi - Editor-in-Chief at A Crítica during the drought of 2010, interviewed on 11-16-2011).

\begin{abstract}
All extreme conditions here are used by our politicians to commit crimes. We had cases of overcharging for the food baskets. They take advantage of the gaps in the law, which allow them to embezzle public funds. We didn't cover people who were suffering because we didn't believe this was a political, electoral and economic benefit. We didn't do that because, if we had, we would be confirming the facts that benefit those politicians (Sérgio Bartholo - Editor-in-Chief at Diário do Amazonas during the 2005 and 2010 droughts, interviewed on 10-28-2011).
\end{abstract}

Despite the focus on the consequences of the droughts and contrary to national and international media coverage, the 
newspapers still did not present the extreme weather conditions as a result of global climate change. Only $3.6 \%$ of the articles examined were on global climate change, less than other disasters such as El Niño', appearing in $14.3 \%$ of the texts. When questioned about this data, editors were skeptical about the low tide being a result of global climate change. The three journalists who were interviewed expressed concern about the credibility of the reported facts and whether they leaned more towards tabloid journalism, something they see happening in the national and international press. They differ on their explanations for the extreme weather conditions:

\begin{abstract}
What we notice from the available data is that there is a need for more scientific study on the subject. This would define what the real situation on the planet is. By saying that, I don't mean that the problem doesn't exist. The issue of global warming in the Amazon has a predictable outcome if no sustainable projects are taken. From my point of view, there are other issues such as politics, the world market policy about the the use of energy sources, and energy shift. Since the Amazon is an ecologically sensitive region, it ends up being discussed quite frequently. (Wilson Nogueira Editor-in-Chief at $A$ Crítica during the drought coverage of 2005, interviewed on 11-03-2011).

The fact is that the periods of low tides and floods are cyclical, that is, they take place every year in the region. I noticed some tabloid journalism coverage in non-local press. The national press reported on it in an almost tabloid way, using it to draw the reader's attention (Hudson Braga - Editor at A Crítica during the drought coverage of 2005, interviewed on 12-09-2011).
\end{abstract}

The newspapers did not give much explanation for the reason so many problems and tragedies were portrayed in their pages, especially A Crítica. Out of all the coverage, only $3.6 \%$ of the journalistic material produced by the two newspapers tried to explain the phenomena that affected thousands of people in the state and mobilized the local, state and federal governments to spend public resources on food baskets, building wells and distributing water filters, among other actions. It is worth noting that $82.1 \%$ of the texts do not mention possible causes for the 2005 and 2010 droughts. According to the sources and skilled readers in the scientific community who read this research, there is a lack of accurate coverage in the articles; they offer readers fragmented information with no proper correlation of cause and effect. Observe: 
what's going on. I can't force the press to publish everything I say in an interview. (Philip Martin Fearnside - Researcher at INPA who has studied environmental problems in the Amazon since 1974 and is one of the sources quoted in the drought coverage of 2005).

\begin{abstract}
Few articles brought more scientific information on the causes of the drought in 2010. After the drought occurred, local media reacted to the news published in other media, particularly information released by INPE. One of the articles, not a very long one, which appeared in A Crítica in November or December confuses you more than it explains. That was the first day. On the second day, it brought more information and had better explanations for what might have happened and what might have been the cause. So, we notice that there is still a lack of preparation on the journalists' part to decode and transmit scientific information in a clear and correct manner. Sometimes it's not even correct (Ocimar Antonio Manzi Researcher at INPA and executive manager of the LBA program, interviewed on 02-02-2012).
\end{abstract}

The readers and the sources who were interviewed about the 2005 and 2010 drought did not see the credibility of the facts as questionable; they did not see that they were forced to write more dramatic articles in order to increase newspaper sales, something which Bucci (2000, p.30) labels 'tabloid journalism' and classifies as a "bold-faced and conscious lie". By just reporting on the phenomena instead of reporting on its impacts and ordeals, the editors have forgotten that the news has a responsibility to inform society about extreme weather conditions and how we can prevent future disasters". That is what the root of journalistic coverage should be for these situations" (PEREIRA JÚNIOR, 2006, p. 70). We believe that knowledge and discussions on the causes of low water are essential towards preventing future catastrophes. Therefore, we believe that this aspect weakened the principles of loyalty to the public interest and verification during the coverage.

\title{
5 INDEPENDENT COVERAGE
}

The magnitude of the social and environmental impacts of the extreme tides of 2005 and 2010 inevitably placed the State as one of the protagonists of the coverage. It was up to the government and its agencies to have emergency actions in place to help those affected by the droughts and alleviate the problems caused by the phenomena. Analyzing journalistic texts through the lens of the independent analysis category led us to investigate 
whether there was an approach to the actions and responsibilities of the government related to the causes and effects of the 2005 and 2010 droughts in the light of the general principle of journalism of being an independent power monitor (KOVACH and ROSENSTIEL, 2003). As stated earlier, the two newspapers' quantitative results of content analysis (see Table 2) are similar if we look at the final numbers of the two articles. The data points towards the newspapers using government agencies as a primary source of information and not having a critical position on their responsibilities. However, the interviews revealed different reasons within the newsrooms for these seemingly numerically equivalent results which is why we worked on Diário do Amazonas and $A$ Crítica separately.

Table 2: Results of Content Analysis in the Independence Category

\begin{tabular}{|c|c|c|c|c|c|}
\hline \multirow{2}{*}{$\begin{array}{l}\text { Did it question the } \\
\text { government's actions for } \\
\text { minimizing the consequences } \\
\text { of the } 2005 / 2010 \text { droughts? }\end{array}$} & \multicolumn{2}{|c|}{ A Crítica } & \multicolumn{2}{|c|}{$\begin{array}{c}\text { Diário do } \\
\text { Amazonas }\end{array}$} & \multirow{2}{*}{$\begin{array}{c}\text { General } \\
2005 / 2010\end{array}$} \\
\hline & $\begin{array}{c}2005 \\
\%\end{array}$ & $\begin{array}{c}2010 \\
\%\end{array}$ & $\begin{array}{c}2005 \\
\%\end{array}$ & $\begin{array}{c}2010 \\
\%\end{array}$ & \\
\hline Yes & 60.7 & 34.1 & 34.8 & 20.0 & 38.4 \\
\hline No & 39.3 & 65.9 & 65.2 & 80.0 & 61.6 \\
\hline \multirow{2}{*}{$\begin{array}{l}\text { Does the report address } \\
\text { the efficiency of the } \\
\text { implementation and the } \\
\text { measures taken by the } \\
\text { Government to alleviate the } \\
\text { effects of the droughts? }\end{array}$} & \multicolumn{2}{|c|}{ A Crítica } & \multicolumn{2}{|c|}{$\begin{array}{l}\text { Diário do } \\
\text { Amazonas }\end{array}$} & General \\
\hline & $\begin{array}{c}2005 \\
\%\end{array}$ & $\begin{array}{c}2010 \\
\%\end{array}$ & $\begin{array}{c}2005 \\
\%\end{array}$ & $\begin{array}{c}2010 \\
\%\end{array}$ & $2005 / 2010$ \\
\hline Yes & 0.0 & 7.3 & 8.7 & 0.0 & 4.5 \\
\hline No & 100.0 & 92.7 & 91.3 & 100.0 & 95.5 \\
\hline \multirow{2}{*}{$\begin{array}{l}\text { Did it show the readers } \\
\text { what the government's } \\
\text { responsibilities are? }\end{array}$} & \multicolumn{2}{|c|}{ A Crítica } & \multicolumn{2}{|c|}{$\begin{array}{l}\text { Diário do } \\
\text { Amazonas }\end{array}$} & General \\
\hline & $\begin{array}{c}2005 \\
\%\end{array}$ & $\begin{array}{c}2010 \\
\%\end{array}$ & $\begin{array}{c}2005 \\
\%\end{array}$ & $\begin{array}{c}2010 \\
\%\end{array}$ & $2005 / 2010$ \\
\hline Yes & 3.6 & 17.1 & 17.4 & 15.0 & 13.4 \\
\hline No & 96.4 & 82.9 & 82.6 & 85.0 & 86.6 \\
\hline \multirow{2}{*}{$\begin{array}{c}\text { Did the report address the } \\
\text { issue of the presence or lack } \\
\text { of public policies to prevent } \\
\text { or alleviate the effects of the } \\
\text { droughts? }\end{array}$} & \multicolumn{2}{|c|}{ A Crítica } & \multicolumn{2}{|c|}{$\begin{array}{l}\text { Diário do } \\
\text { Amazonas }\end{array}$} & General \\
\hline & $\begin{array}{c}2005 \\
\%\end{array}$ & $\begin{array}{c}2010 \\
\%\end{array}$ & $\begin{array}{c}2005 \\
\%\end{array}$ & $\begin{array}{c}2010 \\
\%\end{array}$ & $2005 / 2010$ \\
\hline Yes & 10.7 & 2.4 & 8.7 & 0.0 & 5.4 \\
\hline No & 89.3 & 97.6 & 91.3 & 100.0 & 94.6 \\
\hline
\end{tabular}

Source: made by the researchers 
The newspaper Diário do Amazonas used the government as its main source in the articles on the droughts. In $95.6 \%$ (overall average of 2005 and 2010) of both newspapers there was no mention of any effective actions taken by the government in the newspapers. On average, only $16.1 \%$ of all articles questioned what the state responsibilities were and $4.3 \%$ mentioned the lack of public policies on sanitation, education, transportation and economic dynamism which impacted the cities in the Amazonas and their populations. Reporters who were interviewed attribute this data to the government's influence over the company, which prevented the newspaper from taking a more independent stance.

\begin{abstract}
The owner of the newspaper is always interfering, either explicitly or implicitly. There are previously given orders. The guidelines were about "being careful". People were careful not to say that the drought was being politically exploited in a populist and paternalistic way. What we did, in a creative and transversive sort of way, was add a word box with information regarding a bid waiver or the emergency decree that allowed the purchase without bidding. We already knew what we could and could not do. (Sergio Bartholo - Editor-in-Chief at Diário do Amazonas during the 2005 and 2010 droughts, interviewed on 10-28-2011).

I wrote an article about the visit of Minister Ciro Gomes, and finished and edited it. I know that because I was in the building, I wrote the article word for word and left believing that it would be published the way I had written it. To my unpleasant surprise it wasn't, but my name was there and it will be there forever. The next day, when I came into the newsroom and saw it, I cried a lot and said 'since you are paid by the government, why didn't you take my name out of the article?' (Celia Santiago - Reporter at Diário do Amazonas during the drought coverage of 2005, interviewed on 10-27-2011).
\end{abstract}

In 2005, $60.7 \%$ of A Crítica's articles managed to gather information about what local, state and federal governments were doing or why they were not acting to prevent and alleviate the consequences of the low water. In 2010, A Crítica copied what Diário do Amazonas had been doing since 2005 and presented only official announcements and numbers in most of its articles which meant that an average of $61.6 \%$ of the two newspapers' articles did not question the politicians and their stances on the crisis. Contrary to their competitors, the journalists at A Crítica, even though acknowledging that the government had an influence over their company, did not report any government interference in the coverage so as to prevent any actions or omissions from the State. Consider: 
In general, this is because of the whole logistics process. There is, in fact, negligence in that direction because there is always the idea that the best sources for dealing with droughts is the NDMP2 and other agencies. They are considered trustworthy sources. I disagree with that. I think the indigenous people and those who live by the riverside also have their ideas and their ways to organize themselves when dealing with a phenomena. (Wilson Nogueira - Head Editor at A Crítica during the drought coverage of 2005, interviewed on 11-03-2011).

\begin{abstract}
When the coverage started we weren't newsroom editors. We had two executive editors. That hasn't changed. I started in editorial politics and there had never been censorship prior to that. If we lacked depth, it was due to our lack of being prepared and not because the company had pressured us in some way. (Aruana Brianezi - Editor-in-Chief at A Crítica during the drought coverage of 2010 , interviewed on 11 16-2011).
\end{abstract}

Since the reports published by Diário do Amazonas admit that coverage was affected by "other powers, concealed or otherwise, that flow through the channels and veins of journalistic expression" (CHAPARRO, 2001, p.8), it is necessary to have a further look at A Crítica. To better understand what happened in A Crítica we need to consider the following situation: the state didn't have to worry about monitoring the newspapers' coverage. Effectively delivering food baskets and water purification kits, constructing wells and other available public resources to help the population, and any questions about whether the measures were even effective or enforceable took up $4.5 \%$ of both newspapers' coverage. The explanations given by journalists are confirmed in the theory put forth by Frome (2008) who believes nothing has aged so much since then as the lack of newsrooms' ability to deal with environmental issues. Now let us see what the reporters of these newspapers say:

We weren't able to look at that phenomenon on a broader sclae. This is a fact. Without even reviewing the articles, just taking into account what we could do, what we tried to do and what was published we can see that we didn't know how to oppose this discourse (by the government). We didn't know if it we could do all that was expected to happen. We were not able to monitor and see if it all would happen. We had no previous references. We had a drought in 2005 and we could not recover the information to kind of compare that. (Jorge Eduardo - Reporter at A Crítica during the drought coverage of 2010, interviewed on 10-20-2011).

At that time, we journalists had no idea that the problem was much bigger than just the lack of food and water supplies. The problem was the chronic and historical lack of planning on the part of the authorities towards large-scale human and environmental issues. 
We had space in the newsroom to publish, but we were unprepared for this critical work. (Antonio Ximenes - Reporter at A Crítica during the drought coverage of 2005, interviewed on 12-07-2011).

The above reports highlight the lack of governmental policies on social inclusion and basic sanitation in the cities of Amazonas, meaning the impact of the 2005 and 2010 droughts could have been less serious. Isolated communities, the lack of drinking water, disruption of school classes, fuel rationing and other problems would have had less of an impact if the countryside cities had had a sewer treatment system, garbage collection stations and water distribution. According to journalists, however, this fact was well-known yet seemed to be overlooked; $94.6 \%$ of all articles written on this topic had no mention of it which may have given readers the impression that the consequences of the disaster were all just an act of nature.

\begin{abstract}
The downside was letting the government take advantage and get a political bonus. I don't know whether it was intentional or not. Newspapers should have aroused a response. It was a great opportunity to educate on the environment, to alert students, teachers, etc. that we need to be aware of the weather. It was the time to listen to the opinions of scientists, whose words were reduced to captions in small font. (Luiz Castro - State Representative and President of the Environment Facility Committee of ALEAM during the droughts of 2005 and 2010, interviewed on 12-23-2011).
\end{abstract}

Journalists Antônio Ximenes and Jorge Eduardo present an important factor towards understanding the coverage of the low tide: there was no accumulation of knowledge in the newsrooms between the two extreme weather events. The first journalist reveals that in 2005 the reporting team did not have a broader understanding of the phenomena they were covering and therefore failed to recognize that the droughts were not the cause of the problems they were reporting on, but the lack of state interference in the countryside cities of Amazonas. The second journalist makes it clear that little or nothing was learned from the reporters at $A$ Crítica for the first drought and, therefore, the conclusion which Antônio Ximenes and the other team members reached five years earlier did nothing to help their successors carry out broader and more critical coverage of the second drought. Content analysis of the coverage shows that only $13.4 \%$ of articles published address the state's responsibilities for preventing and alleviating consequences of the drought. 
The 2005 drought occurred a year before the elections for President of the Republic, senators, congressmen, governors and deputies, and the 2010 drought occurred before and during the election period of that year. Actions taken to alleviate the effects of low tides involved distributing food, building wells, and other initiatives implemented by the State using federal funds. This was just one more element for the importance of independent media coverage which could have had direct effects on election results. Our research also sought to look into the possibility of using emergency elections to help those affected by the droughts, and assuming that the newsrooms were aware of this, how had they addressed the issue. All the journalists interviewed, from editorin-chiefs to reporters said they were aware of the real risk of using emergency elections to combat the effects of the drought. This is what we noticed:

Elections were used not only for the droughts but for all
great tragedies. Local politicians and the rest of the country
have taken advantage of these situations. Here we've had
many cases of embezzlement. Unfortunately, it is recurrent.
I think the role of the press is to warn people about these
things, to be aware of them. (Wilson Nogueira - Editor-in-
Chief at $A$ Critica during the drought of 2005, interviewed
on 11.03-2011).

Totally (using elections). (Sergio Bartholo - Editor-in-Chief at Diário do Amazonas during the droughts of 2005 and 2010, interviewed on 10-28-2011).

Surely elections were used. Inevitably the state, on the eve of an election, would benefit from assistance due to a catastrophe that it was not responsible for, a natural disaster. This expands especially with the complimentary tone in certain articles highlighting statements from authorities. (Luiz Castro - State Representative and President of the Environmental Commission of ALEAM, interviewed on 12-23-2011).

In this section on the analysis category of independence, we tried to ascertain how the government's responsibilities towards the causes and effects of the 2005 and 2010 droughts were being reported, meaning if the newspapers took the position of independent power monitors. All the data obtained in the content analysis and the interviews reveal that whether because of negative influence from political interests inside the newsrooms or the momentary inability to oppose the official report and use it as the main source of information for the articles, neither 
newspaper offered its readers articles that met the social role of journalism: being the voice of those who are not in office or have the power and making questions with the public interest in mind (KOVACH and ROSENSTIEL , 2003). Frome (2008, p.43) warns us that if journalists "cannot appreciate or contextualize in any form they become victims of people who make more self-interest and extravagant claims".

\section{FINAL CONSIDERATIONS}

The analysis performed on the accuracy and independence of 2005 and 2010 coverage of the droughts in the Amazon revealed weaknesses. In regards to accuracy, we saw coverage that did not omit or overvalue the facts (tabloids) but predominantly presented the ordeals and the government's neglect for information on the causes which are fundamental for reflecting on the prevention of future impacts. The independence of the coverage was besieged by unspeakable relations between government and media in the newsrooms and by the lack of trained journalists who could oppose the official statements. These two factors elected official state sources as the main sources of information and converted most of the articles published in undiscriminating mediums to serve the government's actions in 2005 (pre-election year) and during the elections in 2010 . Thus, the readers who were surveyed could not count on journalism as an independent monitor of power, able to give them a voice and warn them when their rights are being infringed upon; the role journalism has in democratic societies.

*This paper was translated Shanay Freire Berçot Rodrigues and revised by Lee Sharp.

\section{REFERENCES}

BARDIN, Laurence. Análise de Conteúdo. Lisboa/Portugal: Edições 70 LDA, 2010. 
BELMONTE, Roberto Villar. Menos catástrofes e mais ecojornalismo. In: BOAS, Sérgio Vilas. Formação \& informação ambiental: jornalismo para iniciados e leigos. São Paulo: Summus, 2004.

BUCCl, Eugênio. Sobre Ética e Imprensa. São Paulo: Cia da Letras, 2000.

BUENO, Wilson da Costa. Jornalismo Científico no Brasil: os compromissos de uma prática dependente. Tese apresentada à Escola de Comunicações e Artes da Universidade de São Paulo. Depto. de Jornalismo e Editoração. Doutorado. São Paulo, 1984.

BUENO, Wilson da Costa. Comunicação, Jornalismo e Meio Ambiente: teoria e pesquisa. São Paulo: Majoara Editorial, 2007.

CHAPARRO, Manoel Carlos. Linguagem dos Conflitos. Editora Minerva: Coimbra, 2001.

FONSECA, André Azevedo da. Água de fonte só: a magnitude do problema em uma experiência concreta. In: BOAS, Sérgio Vilas. Formação \& informação ambiental: jornalismo para iniciados e leigos. São Paulo: Summus, 2004.

FROME, Michael. Green Ink: uma introdução ao jornalismo ambiental. Curitiba: Editora UFPR, 2008.

GERAQUE, Eduardo. Jornalismo e ecossistemas parecem (mas não são) elos perdidos. In: BOAS, Sérgio Vilas. Formação \& informação ambiental: jornalismo para iniciados e leigos. São Paulo: Summus, 2004.

HYMES, D.H. (1980). Functions of Speech. In: D.H. Hymes, Languages in Education, Washington, D.C.: Center for Applied Linguistics.

IVANISSEVICH, Alícia. Como popularizar a ciência com responsabilidade e sem sensacionalismo. In: BOAS, Sérgio Vilas. Formação \& informação científica: jornalismo para iniciados e leigos. São Paulo: Summus, 2005.

KOVACH, Bill; ROSENSTIEL, Tom. Elementos do Jornalismo. São Paulo: Geração Editorial, 2003.

LASWELL, Harold D. Politics: who gets what? when? how? New York: Whittlesey House, 1936.

MELO, José Marques de. Jornalismo: compreensão e reinvenção. São Paulo: Saraiva, 2009.

MELO, José Marques de; ASSIS, Francisco de. Gêneros Jornalísticos no Brasil. São Bernardo do Campo: Universidade Metodista de São Paulo, 2010. 
OLIVEIRA, Fabíola Imaculada de. Jornalismo Científico e Amazônia: estudo de quatro jornais brasileiros. Dissertação de (Mestrado em Comunicação), Departamento de Jornalismo e Editoração, Escola de Comunicação e Artes da Universidade de São Paulo, 1990.

PENA, Felipe. Teoria do Jornalismo. São Paulo: Contexto, 2005.

PEREIRA JÚNIOR, Luiz Costa. Guia para edição jornalística. Petrópolis, RJ: Vozes, 2006.

SANTOS, J.M. O que é análise de conteúdo. São Paulo: Summus, 1997.

SCHARF, Regina. Economia sustentável é utopia, contradição ou lucro certo? In: BOAS, Sérgio Vilas. Formação \& informação ambiental: jornalismo para iniciados e leigos. São Paulo: Summus, 2004.

SHOEMAKER, Pamela J.; REESE, Sthepen D. Mediating the message, theories on influences on mass media content. 2 ed. White Plains/ NY: Longman, 1996.

SILVA, Marilene Corrêa da. Metamorfoses da Amazônia. Manaus: Editora da Universidade do Amazonas, 1999.

TAUTZ, Carlos. Oxigênio para a energia: entenda a ideia de um "jornalismo para o desenvolvimento". In: BOAS, Sérgio Vilas. Formação \& informação ambiental: jornalismo para iniciados e leigos. São Paulo: Summus, 2004.

TRAQUINA, Nelson. Teorias do Jornalismo - porque as notícias são como são. $2^{a}$. Ed. Florianópolis: Insular, 2005.

WEBER, Robert P. Basic content analysis. 2 ed. Newbury Park/CA: Sage, 1990.

WOLF, Mauro. Teorias da Comunicação. $6^{\mathrm{a}}$ ed. Lisboa: Presença, 2001.

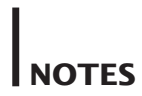

1 El Niño is an atmospheric - oceanic phenomenon characterized by an abnormal warming of surface waters in the tropical Pacific Ocean that may have an effect on regional and global climate, changing wind patterns worldwide, and thus affecting rain patterns in tropical and mid-latitude regions. 
2 The National Department of Mineral Production (DNPM) is a Brazilian federal agency under the Ministry of Mines and Energy. Its headquarters is in Brasilia, Federal District, with constituencies throughout the country represented by superintendents and police stations.

Allan Soljenítsin Barreto Rodrigues is Journalist and writer. He is professor at the Department of Social Communication of the Federal University of Amazonas (UFAM). Master and Doctor in Society and Culture in Amazonia, leader of the Research Group on Communication Culture and Amazon (Trokano) and coordinator of the Advanced Journalism Studies Laboratory at and on Amazon. E-mail: allan30@gmail.com

Grace Soares Costa is manter in Society and Culture in Amazonia, coordinator of the Social Communication program at Martha Falcão College. 